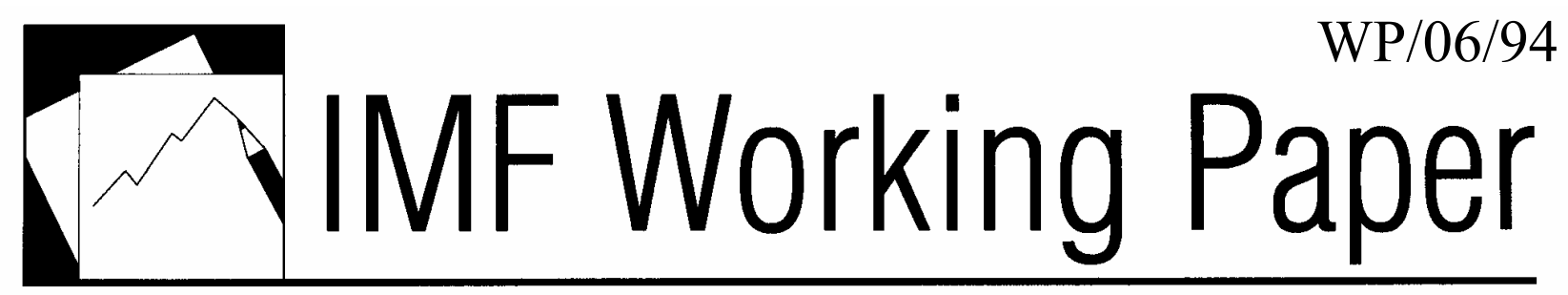

\title{
Interest Rate Determination in Lebanon
}

\author{
Tushar Poddar, Mangal Goswami, \\ Juan Solé, and Victor Echévarria Icaza
}





\title{
IMF Working Paper
}

Middle East and Central Asia Department

Interest Rate Determination in Lebanon

Prepared by Tushar Poddar, Mangal Goswami, Juan Solé, and Victor Echévarria Icaza ${ }^{1}$

Authorized for distribution by Edward Gardner

April 2006

\begin{abstract}

\section{This Working Paper should not be reported as representing the views of the IMF.} The views expressed in this Working Paper are those of the author(s) and do not necessarily represent those of the IMF or IMF policy. Working Papers describe research in progress by the author(s) and are published to elicit comments and to further debate.
\end{abstract}

This paper seeks to understand how interest rates are formed in Lebanon, by focusing on the pass-through from benchmark rates, prevailing liquidity conditions, and the main characteristics of the Lebanese economy, notably its open capital account, fixed exchange rate, high government borrowing requirement, large public debt, and high degree of deposit dollarization. We find that international interest rates are an important element in the determination of interest rates in Lebanon. In particular, the pass-through of global benchmark rates to interest rates on sovereign bonds is about 70 percent. The less-thancomplete pass-through could be attributed to a home-bias effect reflecting a relatively stable and dedicated investor base. The study also shows that interest rates in Lebanon are affected by liquidity conditions as well as perceived sovereign risk.

JEL Classification Numbers: E43, E52

Keywords: interest rates, Lebanon, sovereign risk

Author(s) E-Mail Address: tpoddar@imf.org, mgoswami@imf.org, jsole@imf.org, victoreicaza@yahoo.com

\footnotetext{
${ }^{1}$ The authors are immensely grateful to Edward Gardner for his insights and assistance with all aspects of the research. They would also like to thank Hervé Joly and seminar participants at the Banque du Liban for their helpful comments. The standard disclaimer applies.
} 


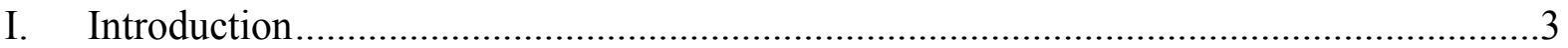

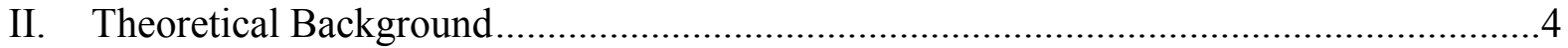

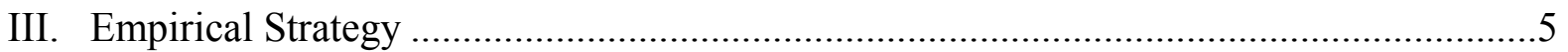

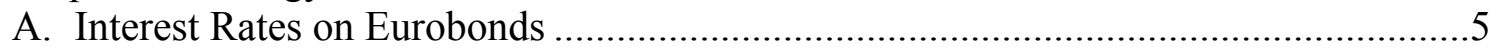

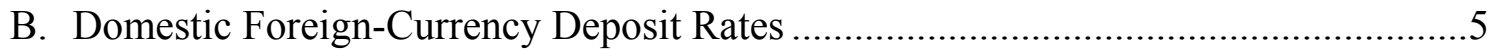

C. Domestic Local-Currency Deposit Rates...........................................................6

D. Interest Rates on Lebanese Pound T-bills........................................................ 7

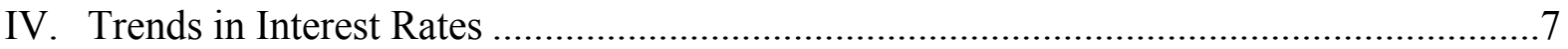

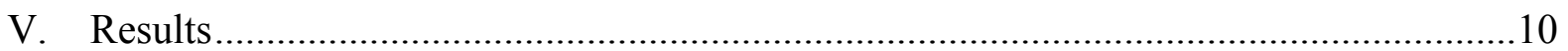

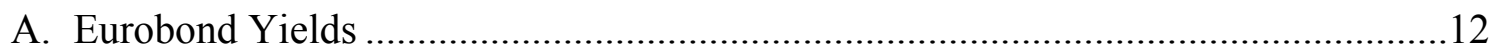

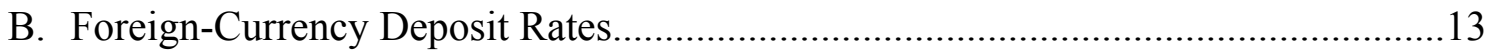

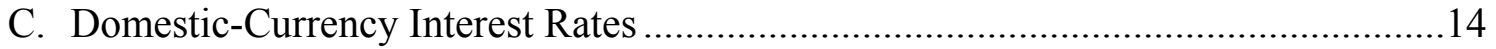

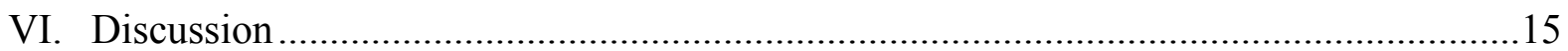

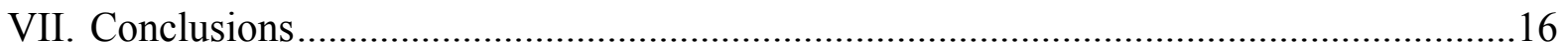

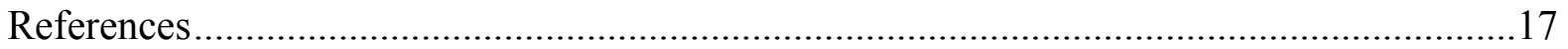

Tables

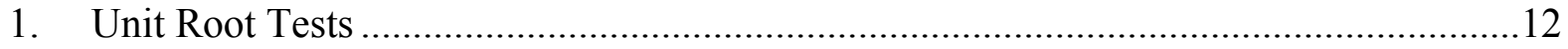

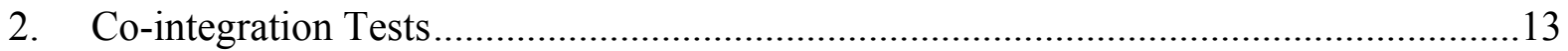

Figures

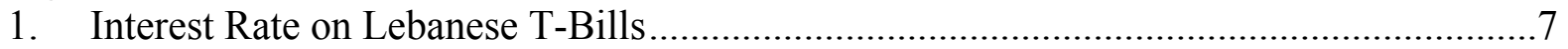

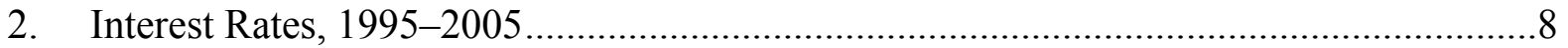

3. Lebanon: Foreign Exchange Reserves..................................................................... 9

4. Interest Rate, Deviations from Trend of M5 (In Percent) and Gross International Reserves (In Logs) .................................................................11

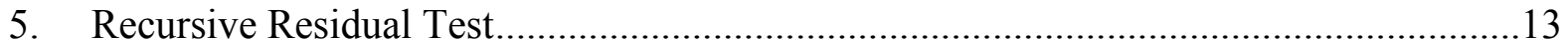

Appendices

I. Data Used in the Study ........................................................................................ 18

II. Full Vector Error Correction Model of the Eurobond Yield .........................................20

III. Full Vector Error Correction Model of the One-Month FCD Interest Rate ...................21

IV. Full Vector Error Correction Model of the Pound Deposit Interest Rate .......................22

Appendix Figures

1. Yields on Three Issues of Five-Year Eurobonds ........................................................ 18

2. Yield on Five-Year Eurobond...................................................................................... 19 


\section{INTRODUCTION}

Since the end of its civil war in 1990, Lebanon has rapidly integrated with global capital markets by tapping investors, especially from its diaspora and from the region. The attractiveness of Lebanon's banking sector in the region derives from its long tradition of regional banking backed by bank secrecy laws and the effects of September 11 on regional asset allocation. As a result, Lebanon's banking sector deposits have grown to nearly three times GDP.

This paper seeks to understand how interest rates are formed in Lebanon by focusing on the main characteristics of its economy, notably its open capital account, fixed exchange rate, high government borrowing requirement, large public debt, high exposure of banks to the sovereign, and high degree of debt and deposit dollarization.

This paper focuses on the three key interest rates in Lebanon - the rate on dollar-denominated sovereign paper (Eurobonds); the rate on foreign-currency deposits offered generally at a premium over Libor; and the rate on local-currency deposits. The main objective of monetary policy in Lebanon is to maintain the exchange rate peg of the Lebanese pound (LL) to the U.S. dollar. The Banque du Liban (BdL) conducts its monetary policy by defining two operational targets: first, the spread between foreign-currency deposit rates and those on international markets, which attracts capital to the country to finance the current account deficit and external debt; second, the spread between local-currency interest rates and dollar interest rates in Lebanon, to promote deposits in Lebanese pounds. These two spreads essentially measure banking sector risk and currency risk, respectively, while the rate on sovereign paper measures sovereign risk.

In principle, the exchange rate peg and the open capital account allow for large flows that would take advantage of any arbitrage opportunities between domestic and international interest rates which would equate risk-adjusted returns. Accordingly, domestic interest rates should respond fully to changes in international rates and in risk perceptions. However, arbitrage opportunities may be limited by a number of factors. First, nonresidents cannot borrow in domestic currency, which reduces their ability to short the currency. Second, currency and interest rate arbitrage may be curtailed by the absence of forward and other derivatives markets. Finally, some observers have argued that the interest parity assumption does not fully apply to the Lebanese situation because the investor base consists mainly of residents or Lebanese nationals who are not very responsive to yield differentials vis-à-vis the rest of the world.

Our results show that the degree of pass-through from international benchmark rates to interest rates in Lebanon is substantial but is less than unity, suggesting the presence of a "home-bias" effect. We also find that the perception of risk has a statistically significant effect on these interest rates, implying that agents consider the probability of default as a significant factor in making their investment decisions. Third, the availability of liquidity in the system also affects interest rates. 
This paper contributes to the literature on interest rate determination in emerging markets by providing a case study of interest rate determination in a vulnerable economy. Our findings suggest that global market conditions and macroeconomic fundamentals have a significant impact on domestic interest rates even for a country with a large and ostensibly committed diaspora.

The rest of the paper is organized as follows. Section II provides the theoretical background to understanding interest rate determination in Lebanon. Section III outlines the empirical strategy and discusses the variables to be used in the analysis. Section IV looks at trends in interest rates in Lebanon over the last decade. Section V presents the main results, while Section VI discusses these results. Section VII concludes.

\section{THEORETICAL BACKGROUND}

The theoretical literature on interest rate determination in emerging markets is based on the concept of arbitrage across financial assets, the trade-off between risk and return of an asset, and the effects of market liquidity on the return of an asset. The remainder of this section briefly discusses each of these concepts and how this study captures them.

When capital is highly mobile, agents will take advantage of even small arbitrage opportunities. In this sense, one would expect that a country's interest rate would be affected by global financial conditions, and thus be linked to international rates such as the LIBOR or the U.S. T-bill rate, which are widely used to benchmark financial contracts. These interest rates are practically risk-free, and thus provide an anchor upon which other elements that affect interest rates (such as liquidity and default risk) can be incorporated into a particular econometric specification (see Kamin and von Kleist, 1999; and Arora and Cerisola, 2001).

Concerning the effects of market liquidity on interest rates, we expect from the theoretical literature that increases in liquidity, i.e., higher demand for Lebanese deposits, would be accompanied by a higher asset price, i.e., a lower rate of return on deposits. ${ }^{2}$ This increase in liquidity for a particular country's asset could arise from a number of factors such as relatively cheap availability of global credit, increased risk in other foreign markets, and changes in the risk appetite of international investors, among others. Changes in the liquidity conditions observed in the market are likely, in turn, to lead to changes in the central bank interest rate policy. For instance, an increase in the desired holdings of Lebanese assets is likely to lead to an easing of interest rate policy by the BdL. Below, we propose a measure of liquidity that attempts to capture the combined effect of changes in liquidity and the reaction function of the central bank.

\footnotetext{
${ }^{2}$ See Lucas (1990) for a seminal contribution on this strand of the literature.
} 
Finally, risk-neutral or risk-averse agents will typically demand higher rates of return in order to invest in assets with higher risk factors (e.g., default risk and exchange rate risk). Alternatively, for a given rate of return, an asset becomes more attractive the lower its risk. In Lebanon's case, the main risks arise from the high level of public debt and the risk of a forced exit from the exchange rate peg.

\section{EMPIRICAL STRATEGY}

Based on the discussion in Section II above, we consider regressions of the form,

$$
i_{t}=\alpha\left(i_{t}^{*}\right)+\beta Z_{t}+\varepsilon_{t},
$$

where fluctuations in the interest rate on sovereign bonds/deposit rates is a function of the yield on comparable international rates, $i_{t}^{*}$, and macroeconomic variables, $Z_{t}$, that capture exchange rate risk, default risk, and liquidity effects. Note that we do not impose any restriction on the coefficient on the international reference interest rate. This is in order to allow for the possibility of a pass-through less than unity. We now turn to a description of the set of macroeconomic variables used in determining each interest rate.

\section{A. Interest Rates on Eurobonds}

Since 1995, the Lebanese government has been issuing dollar-denominated Eurobonds to cover part of its financing need. The interest rate spread between these bonds and U.S. treasury securities should reflect sovereign default risk. We use two variables to capture the effect of sovereign risk on Eurobond interest rates - the level of public debt and gross official foreign exchange reserves. In the Lebanese context, the level of reserves is a good

proxy for default risk inasmuch as it affects the ability of the government to obtain financing from the market. A high level of reserves gives assurances that the government can service its debt in the short run in the event of liquidity constraints, and thus gives confidence that liquidity problems will not unravel into a full blown solvency crisis.

\section{B. Domestic Foreign-Currency Deposit Rates}

The spread between foreign-currency deposits (FCDs) and a benchmark rate such as Libor reflects banking sector risk. Given the banking sector's high exposure to the sovereign and the systemic risks arising from sovereign risk, we expect the same risk factors, public debt and international reserves to be key determinants of the interest rate spread. We also include other variables to measure risk factors. For country- and banking-system-specific factors we use net foreign assets of the banking system. We also include debt denominated in foreign currency to GDP and external current account balance. To measure liquidity factors, we use excess banking sector reserves held at the central bank, deviation from trend of foreign- 
currency deposits, and deviation from trend of broad money (M5). ${ }^{3}$ Since a majority of short-term deposits in foreign currency are under one month (about 65 percent of FCDs as of end-2004), we consider the one-month interest rate as the dependent variable. ${ }^{4}$ For the benchmark, we use one-month rate on Libor to assess the pass-through from international rates to foreign -currency deposit rates in Lebanon. The independent variables are lagged one period to alleviate simultaneity problems.

\section{Domestic Local-Currency Deposit Rates}

The spread between interest rates on local-currency deposits and those on foreign-currency deposits reflects exchange rate risk. We can explain this risk in terms of reserve adequacy indicators and other monetary or fiscal policy variables. A higher level of foreign-currency reserves at the central bank would lower investors' expectations of a depreciation, as well as indicate that the government is likely to encounter less difficulties in financing its deficit. However, one should be careful about making inferences on the direction of causality between international reserves and interest rates, since the central bank is likely to change interest rate policy in response to changes in the level of reserves, in which case causality would run from interest rates to reserves.

Exchange rate risk is also affected by sovereign risk since concerns about the government's solvency can cause a shortfall in financing which increases the risks of an exchange rate depreciation. To measure sovereign risk, we use as independent variables the debt-to-GDP ratio, the ratio of debt in foreign currency to GDP, the external current account balance, net foreign assets of the banking system, and dollarization. Causality between the degree of dollarization and the exchange rate premium can go in either direction. A high spread vis-à-vis FCDs can encourage de-dollarization, but a high degree of dollarization may also reflect market perceptions about exchange rate risk which, in turn, require a rise in domestic interest rates. We lag independent variables one period to alleviate the endogeneity problem.

To measure availability of liquidity, we use deviation from trend of total deposits, excess reserves at the central bank, the spread between one-month FCDs and Libor, and the deviation from trend of LL deposits.

\footnotetext{
${ }^{3}$ Our measure of broad money, M5, includes nonresident deposits which account for about 15 percent of total deposits.

${ }^{4}$ About 90 percent of FCDs are under three months. We also used three-month rates with very similar results.
} 


\section{Interest Rates on Lebanese Pound T-bills}

In the absence of a well-functioning secondary market for T-bills, the rate in the primary market, or alternatively the rate on central bank certificates of deposit (CDs) issued on tap, acts as the key reference interest rate for the economy. ${ }^{5}$ In fact,

Figure 1. Interest Rate on Lebanese T-bills (In percent) inasmuch as the central bank operates the primary T-bill market, which is the main source of placement of excess liquidity, the T-bill rate effectively functions as a monetary policy instrument. The stability of the T-bill rate (Figure 1) reflects the fact that market pressures are absorbed through other means, primarily issuance of $\mathrm{BdL}$ CDs to absorb excess liquidity and central

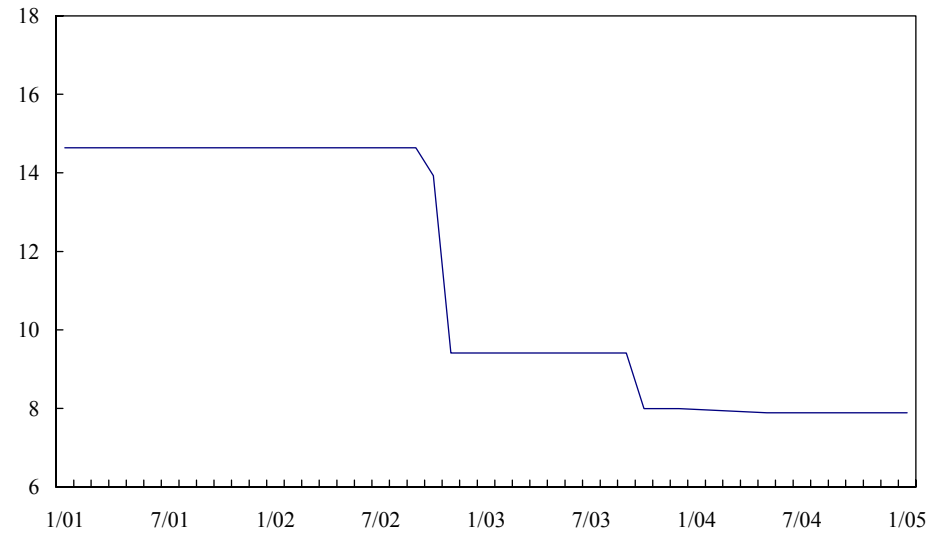
bank financing of the government to meet liquidity shortfalls. Thus, short-term market pressures are filtered out and the T-bill rate adjusts only partially and with a lag to shifts in market forces. Hence, we do not model their determination in the following analysis.

\section{TRENDS IN INTEREST RATES}

Before attempting to identify econometrically causal relationships, a graphical presentation is used to trace the evolution of interests rate since 1995. Figure 2A plots the yield on five-year Lebanese Eurobonds ${ }^{6}$ and those on (nearly risk-free) five-year U.S. paper. As mentioned above, the differential can be taken as a measure of sovereign risk. As such, sovereign risk fluctuated in the 2-5 percent range in 1995-99. In 2000, while rates on five-year U.S. treasuries started falling, the Eurobond rate kept rising. The spread increased sharply starting from mid-2001, peaking at 10.9 percent in September 2002. During this period, the government was finding it difficult to finance its deficit as deposit inflows turned negative, and gross international reserves started falling (Figure 3). The unsustainable situation was reversed by the Paris II donors conference in November 2002, and the promised support to the government brought sovereign risk down sharply in the last quarter of 2002. Since then spreads have come down to about 2.7 percent. The factors that could potentially contribute to the increase in spread are a weakening of underlying macroeconomic fundamentals in Lebanon, a shortage of liquidity available, a lagged reaction of Lebanese interest rates to the

\footnotetext{
${ }^{5}$ Because of Paris II disbursements and exceptional domestic financing, from February to October 2003, the government did not need to issue T-bills, and excess liquidity was mopped up by central bank CDs of various maturities issued on tap.

${ }^{6}$ A series for the period 1995-2003 was constructed by splicing various five-year issues (see Appendix 1).
} 
Figure 2. Lebanon: Interest Rates, 1995-2005

A. Interest Rate on Five-Year to Maturity Eurobond and Five-Year U.S. T-bill

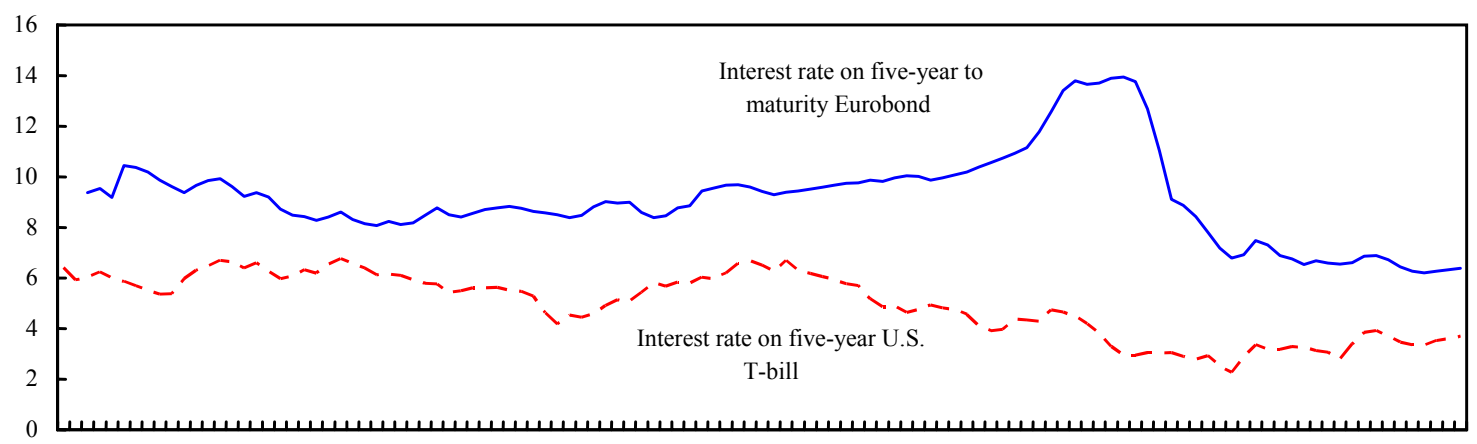

1995M05 1996M02 1996M11 1997M08 1998M05 1999M02 1999M11 2000M08 2001M05 2002M02 2002M11 2003M08 2004M05

B. Interest Rate on One-Month Foreign Currency Deposits and One-Month LIBOR

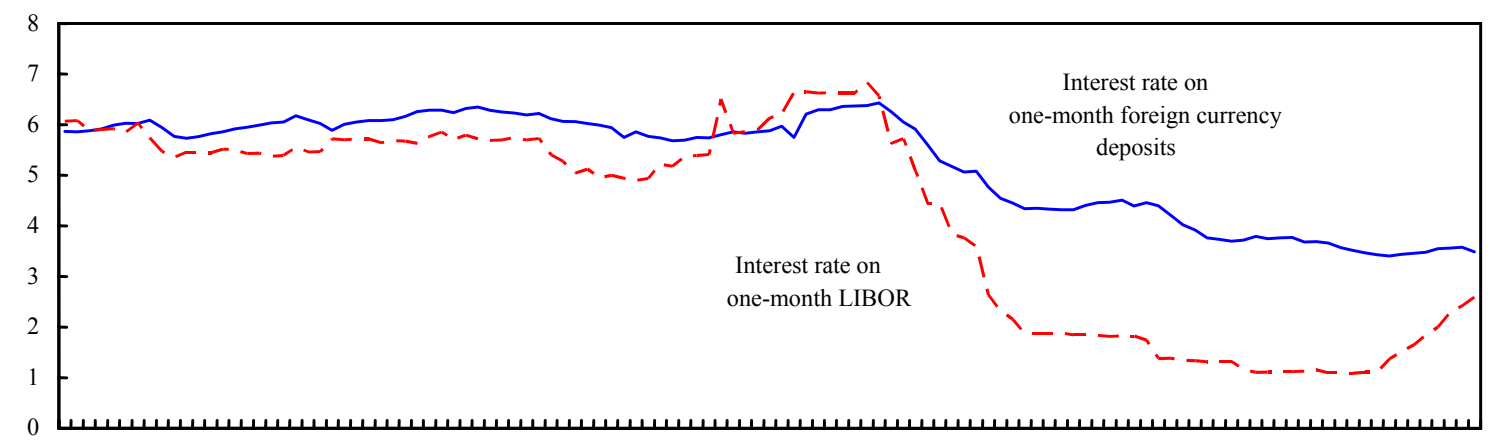

1995M05 1996M02 1996M11 1997M08 1998M05 1999M02 1999M11 2000M08 2001M05 2002M02 2002M11 2003M08 2004M05

C. Interest Rate on One-Month Lebanese Pound Deposits and One-Month Foreign Currency Deposits

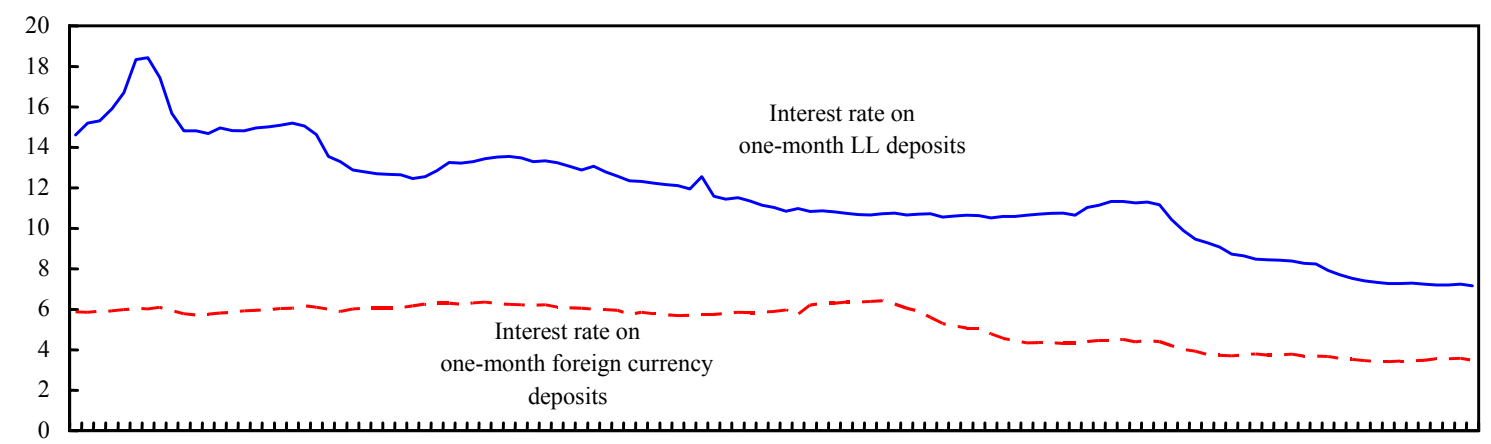

1995M05 1996M02 1996M11 1997M08 1998M05 1999M02 1999M11 2000M08 2001M05 2002M02 2002M11 2003M08 2004M05

Source: Banque du Liban, Financial Forecast Center. 
drop in U.S. interest rates, or a less-than-complete pass-through of U.S. interest rate changes, denoting some form of home bias. Figure 2B shows the spread between one-month U.S. dollar deposits and Libor of a corresponding maturity. ${ }^{7}$ As one might expect, the FCD rate exceeds the Libor rate throughout, except for a brief period in 2000, when Libor rose rapidly. The spread began rising in 2001, as international dollar interest rates fell faster than domestic dollar rates. This observation does not imply that the widening of the spread is caused Figure 3. Foreign Exchange Reserves (In billions of US dollars, right scale) and M5 (In billions of Lebanese Pounds) by the faster dollar interest rate reduction, as underlying risk factors may have been increasing at the same time. The spread between pound-denominated deposits and FCDs, a measure of exchange rate risk, is plotted in Figure 2C. This risk fluctuated substantially over 1995-2003. A spike was recorded in late 1995 , reflecting a period of heightened

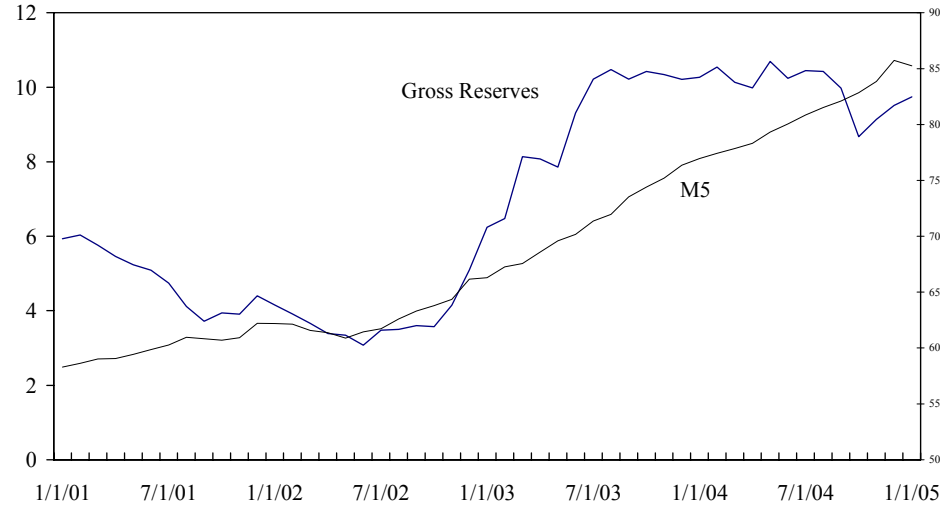
political tension related to the extension/renewal of the president's term. Excluding this episode, the exchange rate risk recorded a trend decrease until late 2000 (4.3 percent for one-month deposits). It then crept up again to 6.9 percent in mid-2002, decreasing again thereafter. The pattern since end-2000 follows that of sovereign risk and likely reflects fiscal dominance in that public finance dynamics are likely to be the dominant factor for the credibility of the exchange rate anchor. Throughout the period, the exchange rate premium was large and positive, implying that agents attributed a significant probability to a depreciation/devaluation, even when the exchange rate was appreciating (until early 1999). Accordingly, the ex post return on pound deposits $^{8}$ consistently exceeded the return on dollar deposits by a large margin, as shown in the figure.

Figure 4 plots spreads on dollar deposits over Libor and LL deposits over dollar deposits against gross reserves and deviations from trend in broad money. In 1995-96, broad money was below trend due to the tensions regarding the renewal of the president's term, and dollar deposit spreads were rising (panel B). Then, money growth picked up but no discernible pattern was seen in spreads. Starting from late 2000, increasing financial market stress led to rising FCD rates and spreads, and a slowing down of money growth. In addition, liquidity conditions in world markets became tight in 2001 after the technology bust in the United States and Europe. The large monetary easing in the United States and Europe

\footnotetext{
${ }^{7}$ A comparison of three-month and six-month rates yields qualitatively similar results. We show one-month rates because most FCDs in Lebanon have a maturity of less than one month.

${ }^{8}$ Defined as the interest rate differential adjusted for changes in the exchange rate.
} 
starting from 2001, followed by an easing of domestic financial tensions after Paris II, led to declines in spreads as discussed in Figure 2 above. Deposit growth finally resumed in late 2002 inspired by the confidence effects of Paris II. Since then, broad money growth has been sustained, while spreads have fallen. The figure, therefore, suggests that deviations from trend in broad money can be taken to be a good indicator of the availability of liquidity, and there appears to be a negative relationship with spreads, more discernibly since late 2000 .

Figure 4 panel C plots spreads on LL deposit rates over dollar deposits and gross international reserves. Until mid-2001, gross reserves were generally increasing while spreads were falling. Financial stress in 2001-02 led to falling reserves, while spreads were increasing. Since Paris II, reserves have shown large increases, while spreads have come down considerably. A similar pattern is observed in panel D with respect to broad money Thus, the panels suggests a negative relationship between reserves and deviations in trend from broad money on the one hand, and spreads on LL deposits on the other.

\section{REsults}

The variables were tested for non-stationarity, and the null hypothesis of a unit root could not be rejected for all variables except for the one-month Libor rate (Table 1). We could first difference the variables to obtain a stationary series. However, the transformation would make it difficult to identify any long-run relationships between the various interest rates and would explain only short-run dynamics. Given that the purpose of the study is to focus on long-term relationships, we avoid first differencing the data, and instead, we employ a vector error correction (VEC) model to investigate the relationships between the different interest rates and our measures for liquidity and sovereign risk.

The VEC model is a restricted vector auto-regression (VAR) designed for use with nonstationary series that are known to be co-integrated. The specification restricts the longrun behavior of the endogenous variables to converge to their co-integrating relationships. As the VEC specification only applies to co-integrated series, we run the Johansen cointegration test prior to VEC specification. This allows us to confirm that the variables are co-integrated and to determine the number of co-integrating equations. Then, the first difference of each endogenous variable is regressed on a one-period lag of the co-integrating equation and lagged first differences of all of the endogenous variables in the system. The results are reported below. 
Figure 4. Interest Rate, Deviations from Trend of M5 (In Percent) and Gross International Reserves (In Logs)
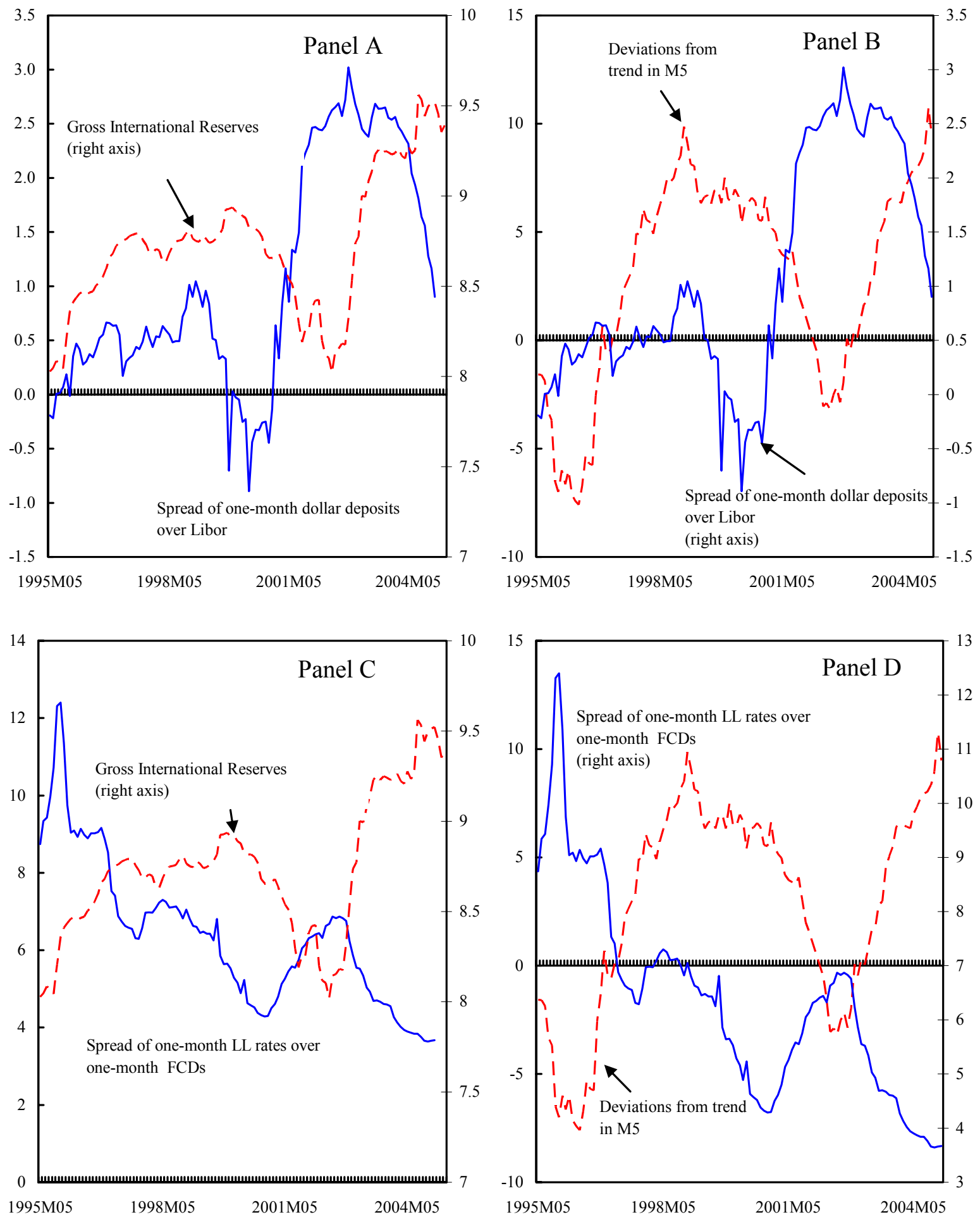

Source: Lebanese authorities and staff estimates. 
Table 1. Unit Root Tests

\begin{tabular}{llrr}
\hline Variable & \multicolumn{1}{c}{ Sample Period } & ADF Statistic & Phillips-Perron \\
\hline Interest rate on foreign-currency deposits & June 1995-January 2005 & -2.64 & -0.01 \\
Interest rate on Eurobonds & June 1995-January 2005 & -1.87 & -1.57 \\
Interest rate on U.S. five-year T-bill & June 1995-January 2005 & -1.46 & -1.32 \\
Gross international reserves & June 1995-January 2005 & -1.27 & -1.24 \\
Foreign-currency debt & June 1995-January 2005 & -0.94 & -1.08 \\
Interest rate on foreign-currency deposits & November 2000-January 2005 & -2.65 & -2.90 \\
Interest rate on LIBOR & November 2000-January 2005 & $*-3.47$ & $*-3.60$ \\
Deviations from M5 & November 2000-January 2005 & -0.21 & -0.39 \\
Gross international reserves & November 2000-January 2005 & 0.16 & -0.29 \\
Gross international reserves & November 2000-January 2005 & -0.02 & -0.22 \\
\hline
\end{tabular}

* Indicates rejection of the null hypothesis at the 5 percent level.

\section{A. Eurobond Yields}

We ran equation (1) as a VEC model to determine the long-run relationship between sovereign yields measured by the yield on Eurobonds, a benchmark rate proxied by the interest rates on five-year U.S. T-bills, sovereign risk captured by foreign exchange reserves, and foreign-currency debt. We used monthly data from May 1995 to January 2005. The longrun relationship is given by ${ }^{9}$

$$
i_{t}^{e b}=0.7 i_{t}^{u s t 5 y}-6.5 \text { gir }+1.4 f c p v t d e b t+49.1
$$

Where $i_{t}^{e b}$ is the yield on five-year Eurobonds, $i_{t}^{u s t 5 y}$ is the interest rate on five-year U.S. T-bills (both in percent), gir is the logarithm of official foreign exchange reserves in millions of U.S. dollars; and fcpvtdebt is the logarithm of privately held foreign-currency debt in millions of U.S. dollars.

The variables are co-integrated when we allow the co-integrating vector to have no trend and an intercept and two lags. As shown in Table 2, the Johansen co-integration test indicates that there is only one co-integrating vector. The first line in the table tests the hypothesis of no co-integration. The hypothesis is rejected in favor of co-integration. The second line tests the hypothesis of one co-integrating vector against the alternative that both series are stationary. One can think of the alternative hypothesis as saying there are two co-integrating equations. We can't reject the null in this latter case. The coefficients are significant (standard deviations are shown in parenthesis) and have the expected signs: an increase in reserves or a decrease in foreign-currency debt are associated with lower Eurobond yields. An increase of

\footnotetext{
${ }^{9}$ The full VEC Model is presented in Appendix 2.
} 
100 basis points in U.S. T-Bills would result in an increase of 70 basis points in Eurobond yields. A one percent increase in the foreign-currency debt (about $\$ 75$ million based on the average value over the period) would increase yields by 1.4 basis points, while a one percent increase in international reserves (about $\$ 65$ million based on the average value over the period) would reduce Eurobond yields by 6.5 basis points.

Table 2. Co-integration Tests

\begin{tabular}{lrrrr}
\hline & & & & \\
Equation & Eigen-Value & Trace Statistic & $\begin{array}{c}\text { Hent } \\
\text { Critical Value }\end{array}$ & $\begin{array}{c}\text { Hypothesized } \\
\text { Number of CE(s) }\end{array}$ \\
\hline Foreign-currency deposits & 0.44 & 56.70 & 54.08 & None * \\
& 0.34 & 30.60 & 35.19 & At most 1 \\
Lebanese pound deposits & 0.36 & 54.98 & 54.08 & None * \\
Eurobonds & 0.30 & 34.43 & 35.19 & At most 1 \\
& 0.25 & 53.85 & 40.17 & None * \\
& 0.14 & 21.70 & 24.28 & At most 1 \\
\hline
\end{tabular}

* Denotes rejection of hypothesis at the 5 percent level.

\section{B. Foreign-Currency Deposit Rates}

To test for structural breaks in the sample period we used a recursive residuals test (Figure 5), which showed that there was significant parameter instability in the data in October 2000. Hence, we ran the VEC model for the second half of the period, i.e., $2000 \mathrm{M} 11$ to $2005 \mathrm{M} 1$.

We employed the Johansen co-integration test of FCDs, onemonth Libor, deviations from trend of M5, gross international reserves, and the dollarization ratio. The variables are co-integrated when we allow the co-integrating vector to have no trend and an intercept and two lags. As shown in Table 2, the Johansen

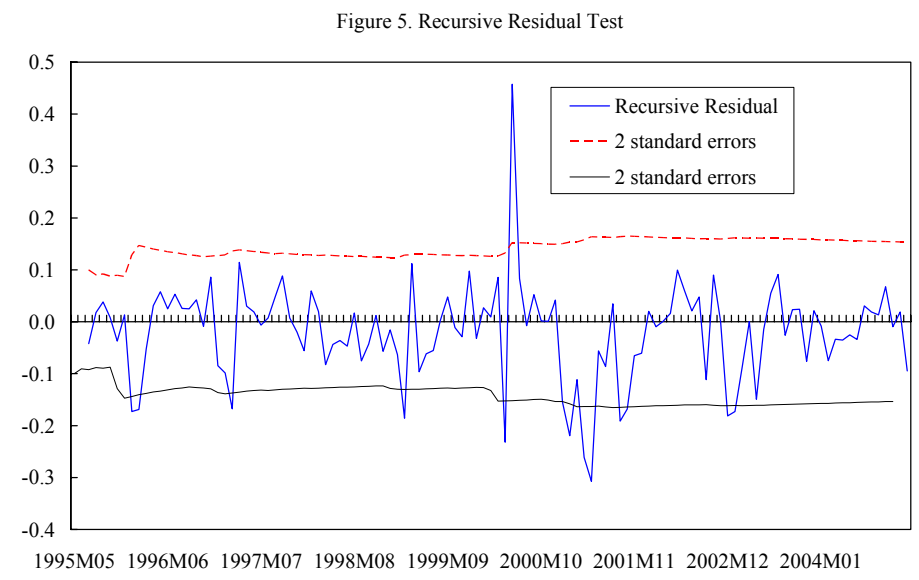
co-integration test indicates that there is only one co-integrating vector. 
Equation 3 reports the main results. Given the structural break, we present results for the latter half of the sample period. The full Vector Error Correction Model is shown in Appendix 3.

$$
i_{t}^{f c d 1 m}=\underset{(0.01)}{0.4 i_{t}^{l i b 1 m}-0.1 \operatorname{devM}(-0.1)-0.6 \operatorname{gir}(-1)-7.7 d z n(-1)+41.8}
$$

Where $i_{t}^{f c d 1 m}$ is the interest rate on one-month dollar deposits, $i_{t}^{l i b 1 m}$ is the one-month dollar LIBOR, devM5 is the deviation from trend of broad money (M5), gir is gross international reserves, while $d z n$ is the dollarization ratio, i.e., the ratio of foreign-currency deposits to total deposits.

Overall, our results suggest that there was a pass-through of about 40 percent from Libor to FCDs over the period November 2000 to January 2005. An increase in M5 from trend by 1 percent leads to a reduction in FCD rates by 0.1 basis points. A one percent increase in international reserves led to a decrease of 0.6 basis points, while an increase of one percentage point in the dollarization ratio decreased FCD rates by 7.7 basis points. All other variables related to banking sector risk and liquidity were not significant and are not reported here.

\section{Domestic-Currency Interest Rates}

The dependent variable is taken to be the rates on one-month deposits in Lebanese pounds (LL) as a majority of deposits are under one month. Since Lebanese pound rates are closely associated with FCD rates, our benchmark rate is the FCD rate which is used as an independent variable. To compare our results with those on FCDs, we use the same sample period of November 2001 to January 2005.

We find a co-integrating relationship between LL deposit rates, one-month FCDs, deviation of M5 from trend, and gross international reserves. The variables are co-integrated when we allow the co-integrating vector to have no trend and an intercept with four lags. As shown in Table 2, the Johansen co-integration test indicates that there is only one co-integrating vector.

Upon estimating the VEC model, the following long-term relationship was found between pound deposit rates, FCD rates, deviation of M5 from trend, and official reserves: ${ }^{10}$

$$
i_{t}^{l l d 1 m}=\underset{(0.02)}{0.9} i_{t}^{f c d 1 m}(-1)-\underset{(0.009)}{0.2 \operatorname{devM} 5(-1)}-\underset{(0.09)}{\operatorname{gir}(-1)}+15.4
$$

This relation can be interpreted as the medium- to long-term constraints facing the central bank. Higher reserves are associated with lower pound deposit rates, while an increase in the

\footnotetext{
${ }^{10}$ The full VEC model and its impulse responses are presented in Appendix 4. Also, causality tests show that reserves Granger-cause the exchange rate premium, but not the opposite.
} 
FCD has a positive impact on pound deposit rates, albeit less than one. The coefficient on the dollar interest rate is likely to reflect the dollarization of debt. Because an increase in dollar interest rates has a large adverse effect on public finances, it will also undermine confidence in the exchange rate peg, with a resulting increase in the exchange risk premium required in the market. We find that controlling for the effects of gross reserves and deviations from trend of broad money, a unit increase in FCD rates causes a less than unit increase in local currency rates. Thus, changes in reserves and deviations in broad money have an independent effect on local currency rates and not only through FCD rates.

\section{Discussion}

A limitation of our econometric study is the relatively small size of the sample. In particular, the results for FCDs and LL deposit rates are based on about 50 monthly observations. However, small sample sizes for emerging markets are common to most empirical studies in part due to ongoing structural changes in the economy. A second issue is that the sample period has witnessed several exogenous shocks. Prominent among these are the financial stress in 2001-02, the positive effects of the Paris II donor package starting from late 2002, and then the shocks associated with the extension of the President's term in fall 2004. These shocks could affect the stability of the parameters. To test for parameter instability we ran the VEC model for different time periods. The Eurobond equation gave point estimates for the interest rate pass-through of 76 for the period 1996-2000 and a pass-through of 63 for 2001-04. These estimates are not very different from those presented in the paper. Similarly, we ran the VEC estimations for FCD rates and LL deposit rates for the pre-2001 period and found the estimates to be quite different, which is consistent with the structural break mentioned in Section $\mathrm{V}$ above. The pass-through from Libor to FCD rates for this period is significantly lower at 30 percent, while a one percent increase in FCD rates increases LL rates by 1.2 percent. Given the evolving nature of the monetary system and structural changes, we believe that the more recent sample period more meaningfully captures the relationships and are thus reported. The period since February 2005 was affected by exceptional measures adopted by the BdL in the face of rapid loss of reserves and dollarization in the wake of former Prime Minister Hariri's assassination. This exogenous shock led to parameter instability and hence we do not report results for this period.

A third issue is that there may be some measurement error due to the splicing of the Eurobonds. However, the longer time series for the Eurobond equation should alleviate this concern. We are of the view that due to the above issues, the point estimates of the parameters should not be overly emphasized and should be taken to be more as the mid-point of a range of estimates.

Our findings on the pass-through from benchmark rates to domestic rates in Lebanon are at odds with the findings of, Arora and Cerisola (2001) who find that for nearly all emerging markets in their sample, a unit change in long-term U.S. rates causes a more than unit increase in sovereign bond rates. Given the openness of the capital account and the presumed sophistication of large depositors, the degree of pass through is surprisingly low -0.7 for Eurobond rates, 0.4 for FCD rates, and slightly less for LL deposits. The fact that the pass- 
through is greater for Eurobonds than for FCDs could reflect differences in the investor bases for these instruments. Although market Eurobonds are for the most part held by domestic banks, they are also traded on international markets and are more likely to be held by nonLebanese investors. One would therefore expect arbitrage on Eurobonds to be more active than on FCDs. A fruitful avenue for further research could be to look into the impact of these different pass-through on bank income statements and balance sheets, and the resulting adjustments to borrowing interest rates.

\section{Conclusions}

This study shows that global benchmark interest rates are an important element in the determination of interest rates in Lebanon. Our econometric investigation confirms that there is a substantial pass-through of international interest rates to Eurobonds and domestic dollar deposit rates, albeit lower than one. Given Lebanon's vulnerabilities, the degree of pass through seems relatively muted. This could be attributed to a home-bias effect resulting from a dedicated yield-seeking Lebanese investor base which does not trade actively across asset classes. The study also shows that interest rates in Lebanon are affected by liquidity conditions as well as perceived sovereign risk.

Despite the absence of a full pass-through in the period under consideration, the impact of changes in international interest rates on the government's borrowing costs remains substantial. Much of the government's financing needs is covered through the issuance of market Eurobonds which remain quite sensitive to U.S. interest rates, with a pass-through of 70 percent. Given the relatively short average maturity of the debt, an upward shift in the U.S. yield curve would have a quick and large negative impact on the budget.

The study also suggests a negative relationship between international reserves and interest rates. The analysis can help shed some light on the debate about the optimal level of international reserves, which depends on balancing the holding cost of reserves against the benefits deriving from lower spreads.

The key issue for Lebanese policymakers is how to bring Lebanese interest rates down, in order to reduce its massive interest bill. This study confirms that stronger fundamentals will be required to achieve this. 


\section{REFERENCES}

Arora, Vivek, and Martin Cerisola, 2001, "How Does U.S. Monetary Policy Influence Spreads in Emerging Markets?" Staff Papers, International Monetary Fund, Vol. 48, Issue 3/4, pp. 474-98.

Edwards, Sebastian, and Mohsin S. Khan, 1985, "Interest Rate Determination in Developing Countries," Staff Papers, International Monetary Fund, Vol. 32 (September), pp. 377-403.

Grilli, Vittorio, and Nouriel Roubini, 1992, "Liquidity and Exchange Rates," Journal of International Economics, Vol. 32, pp. 339-52.

Kamin, Steven B., and Karsten von Kleist, 1999, "The Evolution and Determinants of Emerging Market Credit Spreads in the 1990s," Working Paper No. 68 (Basel: Bank for International Settlements).

Lucas, Robert E., Jr., 1990, “Liquidity and Interest Rates," Journal of Economic Theory, Vol. 50, pp. 237-64. 


\section{Data Used in the Study}

This appendix provides a brief description of the data used in the various models.

\section{Eurobond Yield Model}

Lebanese Eurobonds were introduced in 1995. As far as we know, no time series are available on yields for given remaining maturities. Daily data on various issues are available from Bloomberg. Monthly aggregates were calculated as the simple average of daily observations. By splicing yield data on three different five-year Eurobond issues that are relatively liquid (Appendix Figure 1), we were able to obtain one time series for the period 1995 to 2003 (Appendix Figure 2).

Appendix Figure 1. Yields on Three Issues of Five-Year Eurobonds

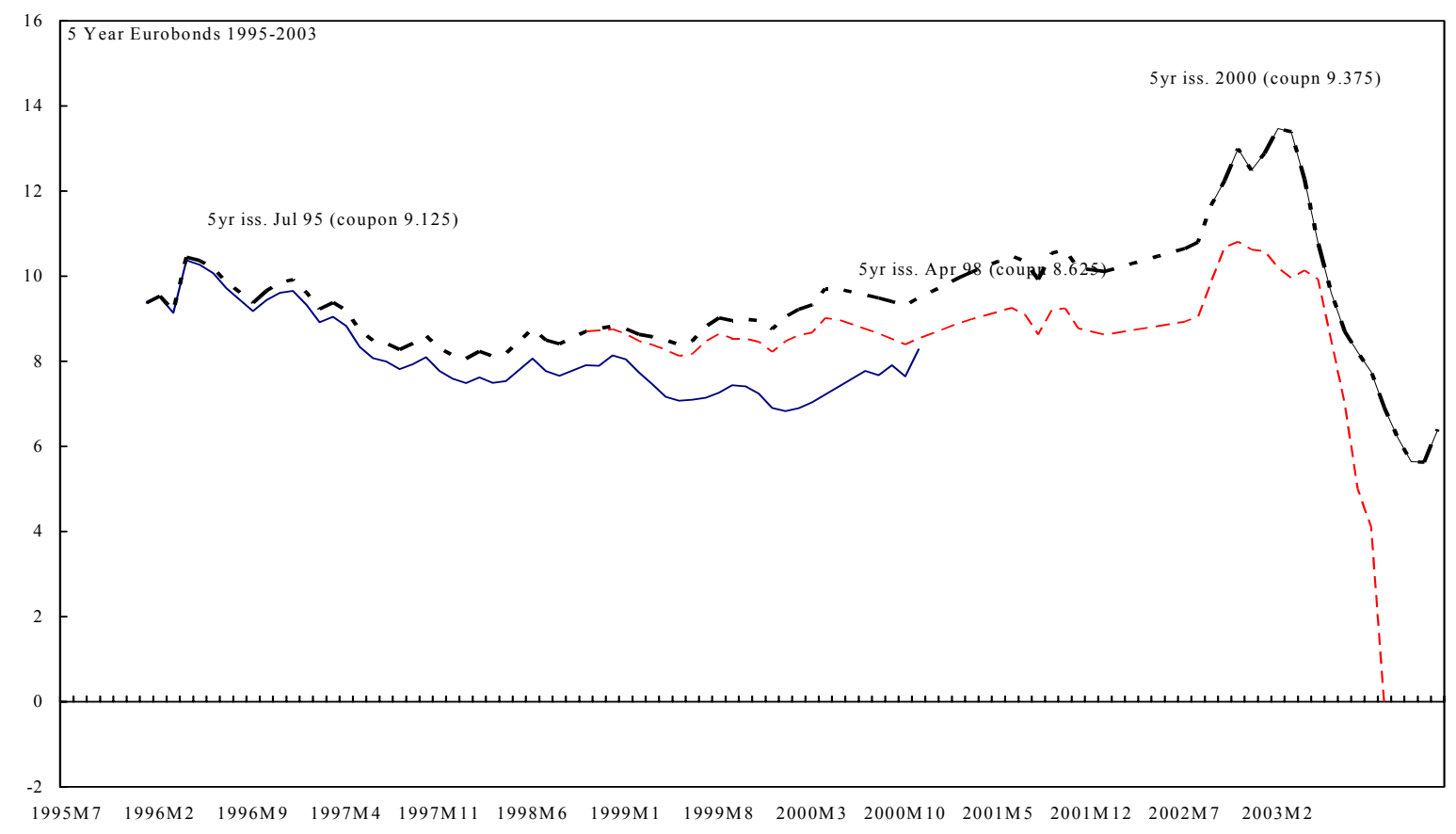


Appendix Figure 2. Yield on Five-Year Eurobond (Spliced Series)

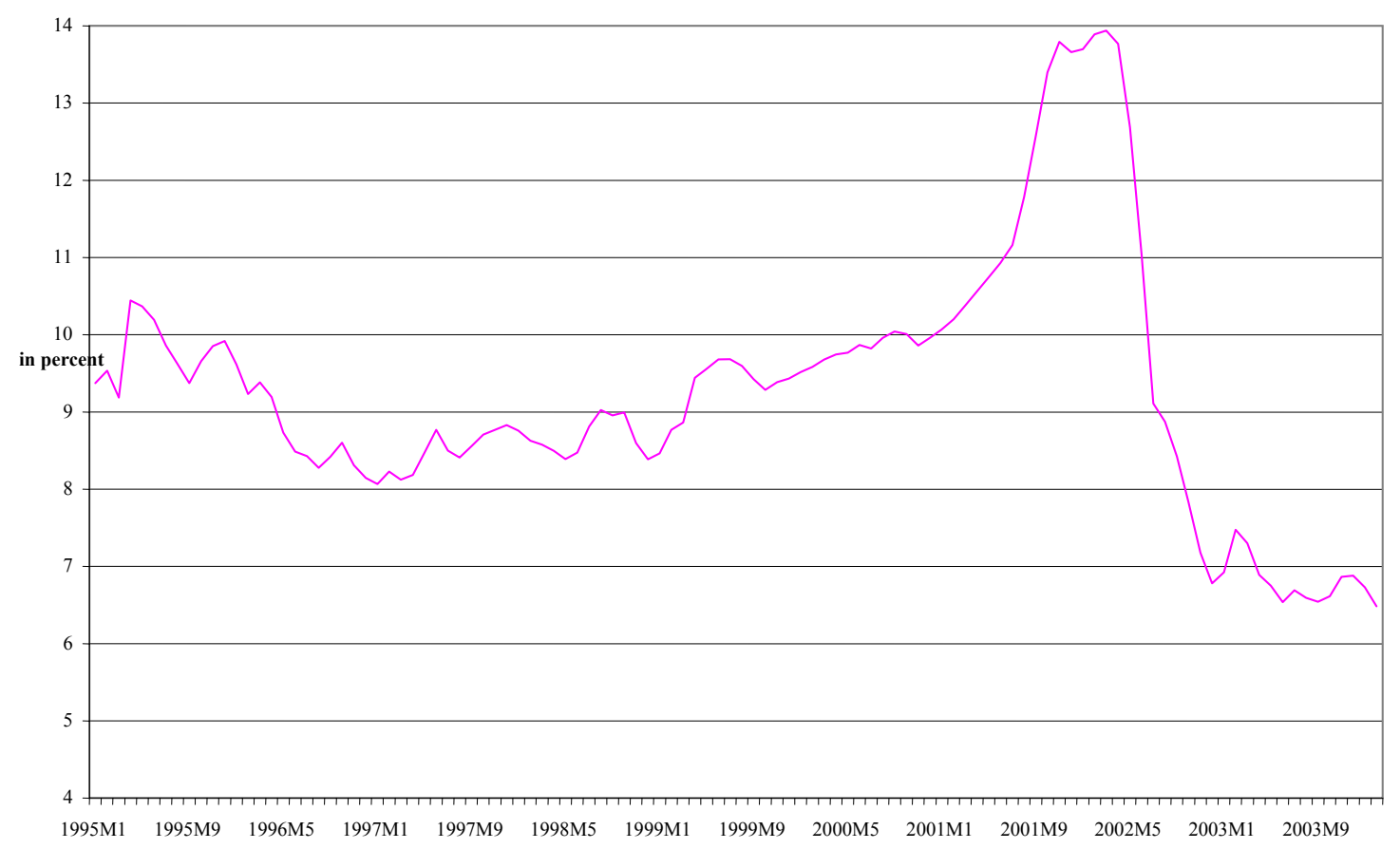

Interest rates on five-year U.S. T-bills were obtained from http://www.forecasts.org/. Although the Banque du Liban does not provide a monthly series of official reserves, they do provide a series for foreign currencies held by the central bank (in U.S. dollars), which was used as a proxy for reserves. Foreign-currency debt held by the market was obtained by subtracting Paris II disbursements and Eurobonds held by the central bank from the series called "external debt" on the BdL website.

\section{FCD Interest Rate Model}

Data on interest rates on foreign-currency deposits (in U.S. dollars, with maturities of one month, three months, six months, and one year) were provided by the Banque du Liban. These data are not available prior to 1995. LIBOR data were obtained from IFS.

\section{Pound Deposit Interest Rate Model}

Data on interest rates on pound deposits (with maturities of one month, three months, six months, and one year) were provided by the Banque du Liban. Data on corresponding T-bill interest rates were downloaded from the BdL website. 
Full Vector Error Correction Model of the Eurobond Yield

\begin{tabular}{|c|c|c|c|}
\hline Co-integrating Equation: & CointEq1 & \multicolumn{2}{|l|}{ Variable } \\
\hline I_EBUPDATED & $T_{-1}$ & CointEq1 & $\begin{array}{c}-0.190901 \\
-0.04304 \\
{[-4.43534]}\end{array}$ \\
\hline I_UST5Y & $\begin{array}{r}-0.665155 \\
-0.16182 \\
{[-4.11049]} \\
\end{array}$ & D(I_EBUPDATED(-1)) & $\begin{array}{l}0.481078 \\
-0.09358 \\
{[5.14068]} \\
\end{array}$ \\
\hline GROSS INTERNATIONAL RESERVES & $\begin{array}{r}6.461906 \\
-0.35814 \\
{[18.0430]} \\
\end{array}$ & D(I_EBUPDATED(-2)) & $\begin{array}{c}0.018 \\
-0.092 \\
{[0.19224]} \\
\end{array}$ \\
\hline D_EXT_PR & $\begin{array}{r}-1.443621 \\
-0.24556 \\
{[-5.87886]} \\
\end{array}$ & D(I_UST5Y(-1)) & $\begin{array}{c}0.023637 \\
-0.1143 \\
{[0.20681]} \\
\end{array}$ \\
\hline \multirow[t]{7}{*}{ C } & -49.14781 & D(I_UST5Y(-2)) & $\begin{array}{c}-0.039684 \\
-0.11277 \\
{[-0.35191]} \\
\end{array}$ \\
\hline & & $\mathrm{D}(\mathrm{GIR}(-1))$ & $\begin{array}{c}-0.744134 \\
-0.50153 \\
{[-1.48373]} \\
\end{array}$ \\
\hline & & $\mathrm{D}(\mathrm{GIR}(-2))$ & $\begin{array}{c}0.602447 \\
-0.52301 \\
{[1.15188]} \\
\end{array}$ \\
\hline & & D(DEBT_FC(-1)) & $\begin{array}{c}-0.835575 \\
-0.59341 \\
{[-1.40808]} \\
\end{array}$ \\
\hline & & D(DEBT_FC(-2)) & $\begin{array}{c}-0.428594 \\
-0.59426 \\
{[-0.72122]} \\
\end{array}$ \\
\hline & & $\mathrm{C}$ & $\begin{array}{c}0.020072 \\
-0.03499 \\
{[0.57370]}\end{array}$ \\
\hline & & $\begin{array}{l}\text { Adj. R-squared } \\
\text { Sample period } \\
\text { Standard errors in () and }\end{array}$ & $\begin{array}{c}0.416 \\
1995 \mathrm{M} 10-2005 \mathrm{M} 1 \\
\text {-statistics in [ ] }\end{array}$ \\
\hline
\end{tabular}


Full Vector Error Correction Model of the One-Month FCD Interest Rate

\begin{tabular}{|c|c|c|c|}
\hline Co-integrating equation: & CointEq1 & \multicolumn{2}{|l|}{ Variable } \\
\hline I_FCD1M & 1 & CointEq1 & $\begin{array}{c}-0.521949 \\
-0.14892 \\
{[-3.50487]} \\
\end{array}$ \\
\hline I_LIB1M & $\begin{array}{r}-0.424267 \\
-0.01253 \\
{[-33.8696]} \\
\end{array}$ & D(I_FCD1M(-1)) & $\begin{array}{c}0.285269 \\
-0.17046 \\
{[1.67355]} \\
\end{array}$ \\
\hline DEVM5(-1) & $\begin{array}{r}0.077365 \\
-0.00604 \\
{[12.8114]} \\
\end{array}$ & D(I_FCD1M(-2)) & $\begin{array}{c}-0.078023 \\
-0.1383 \\
{[-0.56417]} \\
\end{array}$ \\
\hline $\operatorname{GIR}(-1)$ & $\begin{array}{r}0.621659 \\
-0.10117 \\
{[6.14498]} \\
\end{array}$ & D(I_LIB1M(-1)) & $\begin{array}{c}-0.036554 \\
-0.07808 \\
{[-0.46816]} \\
\end{array}$ \\
\hline DOLLARIZATION(-1) & $\begin{array}{r}7.681166 \\
-0.74404 \\
{[10.3313]} \\
\end{array}$ & D(I_LIB1M(-2)) & $\begin{array}{c}-0.091246 \\
-0.06248 \\
{[-1.46031]} \\
\end{array}$ \\
\hline \multirow[t]{8}{*}{$\mathrm{C}$} & -41.83587 & $\mathrm{D}(\mathrm{DEVM} 5(-1))$ & $\begin{array}{c}0.002824 \\
-0.02329 \\
{[0.12128]} \\
\end{array}$ \\
\hline & & D(DEVM5(-2)) & $\begin{array}{c}0.03768 \\
-0.02045 \\
{[1.84290]} \\
\end{array}$ \\
\hline & & $\mathrm{D}(\mathrm{GIR}(-1))$ & $\begin{array}{c}-0.087414 \\
-0.19796 \\
{[-0.44157]} \\
\end{array}$ \\
\hline & & $\mathrm{D}(\operatorname{GIR}(-2))$ & $\begin{array}{c}-0.730956 \\
-0.21994 \\
{[-3.32347]} \\
\end{array}$ \\
\hline & & D(DOLLARI(-1)) & $\begin{array}{c}1.803565 \\
-3.06451 \\
{[0.58853]} \\
\end{array}$ \\
\hline & & D(DOLLARI(-2)) & $\begin{array}{c}1.489552 \\
-3.09742 \\
{[0.48090]} \\
\end{array}$ \\
\hline & & C & $\begin{array}{c}-0.063507 \\
-0.01905 \\
{[-3.33426]} \\
\end{array}$ \\
\hline & & $\begin{array}{l}\text { Adj. R-squared } \\
\text { Sample period } \\
\text { Standard errors in }\end{array}$ & $\begin{array}{c}0.5866 \\
\text { 2000M11-2005M1 } \\
\text { d t-statistics in [] }\end{array}$ \\
\hline
\end{tabular}


Full Vector Error Correction Model of the Pound Deposit Interest Rate

\begin{tabular}{|c|c|c|c|c|c|}
\hline Co-integrating equation: & CointEq1 & \multicolumn{2}{|l|}{ Variable } & \multicolumn{2}{|l|}{ Variable } \\
\hline I_LLD1M & 1 & CointEq1 & $\begin{array}{c}-0.683568 \\
-0.28406 \\
{[-2.40646]} \\
\end{array}$ & & \\
\hline I_FCD1M(-1) & $\begin{array}{r}-0.907008 \\
-0.01831 \\
{[-49.5452]} \\
\end{array}$ & D(I_LLD1M(-1)) & $\begin{array}{l}0.670835 \\
-0.22861 \\
{[2.93445]} \\
\end{array}$ & D(DEVM5(-1)) & $\begin{array}{l}0.128246 \\
-0.06402 \\
{[2.00331]} \\
\end{array}$ \\
\hline DEVM5(-1) & $\begin{array}{r}0.219949 \\
-0.00978 \\
{[22.4951]} \\
\end{array}$ & D(I_LLD1M(-2)) & $\begin{array}{c}0.091753 \\
-0.26129 \\
{[0.35115]} \\
\end{array}$ & $\mathrm{D}(\mathrm{DEVM} 5(-2))$ & $\begin{array}{c}0.160383 \\
-0.07095 \\
{[2.26060]} \\
\end{array}$ \\
\hline $\operatorname{GIR}(-1)$ & $\begin{array}{r}1.04268 \\
-0.09077 \\
{[11.4875]}\end{array}$ & D(I_LLD1M(-3)) & $\begin{array}{c}-0.045663 \\
-0.23431 \\
{[-0.19489]}\end{array}$ & D(DEVM5(-3)) & $\begin{array}{c}0.089036 \\
-0.0651 \\
{[1.36771]}\end{array}$ \\
\hline \multirow[t]{7}{*}{$\mathrm{C}$} & -15.42431 & 1 D(I_LLD1M(-4)) & $\begin{array}{c}-0.150274 \\
-0.19588 \\
{[-0.76719]} \\
\end{array}$ & $\mathrm{D}(\mathrm{DEVM} 5(-4))$ & $\begin{array}{c}0.058429 \\
-0.05572 \\
{[1.04865]} \\
\end{array}$ \\
\hline & & $\mathrm{D}(\mathrm{I}$ _FCD1M(-1)) & $\begin{array}{l}-0.59132 \\
-0.35874 \\
{[-1.64832]}\end{array}$ & $\mathrm{D}(\mathrm{GIR}(-1))$ & $\begin{array}{c}-0.949441 \\
-0.33158 \\
{[-2.86338]}\end{array}$ \\
\hline & & $\mathrm{D}(\mathrm{I}$ _FCD1M(-2)) & $\begin{array}{l}-0.801805 \\
-0.39027 \\
{[-2.05451]} \\
\end{array}$ & $\mathrm{D}(\operatorname{GIR}(-2))$ & $\begin{array}{l}-0.869487 \\
-0.42885 \\
{[-2.02750]}\end{array}$ \\
\hline & & $\mathrm{D}\left(\mathrm{I}_{-} \mathrm{FCD} 1 \mathrm{M}(-3)\right)$ & $\begin{array}{c}0.135985 \\
-0.42183 \\
{[0.32237]} \\
\end{array}$ & $\mathrm{D}(\operatorname{GIR}(-3))$ & $\begin{array}{c}-0.429079 \\
-0.52999 \\
{[-0.80959]} \\
\end{array}$ \\
\hline & & $\mathrm{D}(\mathrm{I}$ _FCD1M(-4)) & $\begin{array}{c}-0.023145 \\
-0.35723 \\
{[-0.06479]} \\
\end{array}$ & $\mathrm{D}(\operatorname{GIR}(-4))$ & $\begin{array}{c}-0.765353 \\
-0.44264 \\
{[-1.72907]} \\
\end{array}$ \\
\hline & & & & $\mathrm{C}$ & $\begin{array}{c}-0.16599 \\
-0.05149 \\
{[-3.22351]} \\
\end{array}$ \\
\hline & & & & $\begin{array}{l}\text { Adj. R-squared } \\
\text { Sample period } \\
\text { Standard errors i }\end{array}$ & $\begin{array}{l}0.408 \\
2000 \mathrm{M} 11-2005 \mathrm{M} 1 \\
\text { ics in [ ] }\end{array}$ \\
\hline
\end{tabular}

